\title{
Specific Labeling of Rat Brain Substance P Receptor with $\left[{ }^{3} \mathrm{H}\right]$ Physalaemin
}

\author{
PREM MOHINI, SULEIMAN W. BAHOUTH, ${ }^{2}$ DEREK E. BRUNDISH, ${ }^{*}$ AND JOSÉ M. MUSACCHIO ${ }^{3}$
}

Department of Pharmacology, New York University Medical Center, New York, New York 10016 and *Research Centre, Ciba-Geigy Pharmaceuticals, Horsham, West Sussex, RH124BA, United Kingdom

\begin{abstract}
The binding of $\left[{ }^{3} \mathrm{H}\right]$ physalaemin $\left(\left[{ }^{3} \mathrm{H}\right] \mathrm{PHY}\right)$ to rat brain membranes is specific, saturable and reversible in the presence of monovalent cations and peptidase inhibitors. Monovalent cations increase the binding of $\left[{ }^{3} \mathrm{H}\right] \mathrm{PHY}$ in an ionic strength $(\mu)$-dependent manner with an optimal effect at $\mu$ higher than 0.3. Addition of $2.5 \mathrm{~mm} \mathrm{MnCl} \mathrm{M}_{2}$ results in a 2-fold increase in the affinity $\left(K_{D}\right)$ and a $40 \%$ increase in the maximal receptor density $\left(B_{\max }\right)$. Scatchard analysis under these conditions indicates the existence of a single population of noninteracting sites with $K_{\mathrm{D}}$ of $3.6 \mathrm{~nm}$ and $\mathrm{a} B_{\max }$ of $76 \mathrm{fmol} / \mathrm{mg}$ of protein. Substance $P$ (SP) and physalaemin are equipotent in inhibiting the binding of $\left[{ }^{3} \mathrm{H}\right] \mathrm{PHY}$, whereas the potency of SP(2-11), SP(3-11), and SP(4-11) decreased in inverse proportion to their length. The relative affinity of the different tachykinins, SP, and SP fragments in competing with $\left.{ }^{3} \mathrm{H}\right] \mathrm{PHY}$ correlates with their potency to stimulate several bioassay systems, indicating that $\left.{ }^{3} \mathrm{H}\right] \mathrm{PHY}$ labels a physiologically relevant binding site that correspond to the SP-P tachykinin receptor. Guanine nucleotides completely abolish the increase in the binding of $\left[{ }^{3} \mathrm{H}\right] \mathrm{PHY}$ produced by $2.5 \mathrm{~mm} \mathrm{MnCl}_{2}$, but in its absence, the nucleotides reduce binding only by $15 \%$. Guanine nucleotides reduce binding to the same level regardless of the presence or absence of the divalent cation. Regional distribution studies confirm that the density of SP receptors is maximal in the olfactory bulb, followed by the hypothalamus, striatum, hippocampus, cortex, and cerebellum.
\end{abstract}

The substance $P(\mathrm{SP}$ )-related peptide physalaemin (PHY) (pGluAla-Asp-Pro-Asn-Lys-Phe-Tyr-Gly-Leu-Met-NH2) is a naturally occurring tachykinin, originally isolated from frog skin (Erspamer et al., 1964). Both peptides have a similar spectrum of physiological activities that includes depolarization of spinal cord neurons (Konishi and Otsuka, 1974), hypotension (Tregear et al., 1971), contraction of the guinea pig ileum (Bury and Mashford, 1977), and stimulation of salivary secretions (Liang and Cascieri, 1979). The results of the analysis of SP and its related peptides on various pharmacological preparations have lead to the subdivision of the tachykinin receptors

Received August 28, 1984; Revised January 2, 1985 ;

Accepted January 2, 1985

\footnotetext{
${ }^{1}$ This work was supported in part by United States Public Health Services Grants DA-02013 and MH-29591, and was presented by S. W. B. in partial fulfillment of the requirements for the degree of Doctor of Philosophy in the Department of Pharmacology of New York University. J. M. M. is a recipient of Research Scientist Award MH-17785

2 Present address: Department of Pharmacology, State University of New York at Stony Brook, Stony Brook, NY 11794.

${ }^{3}$ To whom correspondence should be addressed.
}

into two types. One is the SP-P receptor, which interacts preferentially with PHY and SP and has lower affinity for eledoisin and kassinin (Lee et al., 1982). Tissues that have a preponderance of the SP-P receptor include rat brain and salivary glands and the guinea pig ileum. SP is the putative neurotransmitter in mammalians for the SP-P receptor. The other type is the SP-E receptor, which interacts preferentially with eledoisin and kassinin and has lower affinity for SP and PHY. Tissues that have a preponderance of the SP-E receptor include the rat vas deferens, dog duodenum, and the dog and hamster urinary bladder (Lee et al., 1982). A third tachykinin receptor, SP-K, has recently been reported with preferential affinity for neurokinin $A^{4}$ (Buck et al., 1984). Neurokinin B (Kangawa et al., 1983; Kimura et al.,1983), another recently discovered peptide, is very effective in inhibiting the binding of [ ${ }^{125}$-Bolton Hunter] eledoisin (Buck et al., 1984). The recent discovery of several peptides in mammalians suggests that the tachykinin receptor classification will have to be revised to accommodate the new members of the group (Buck et al., 1984)

[ ${ }^{125}$-Bolton Hunter]SP has been used successfully to label the SP receptor in rat brain synaptosomal membranes (Cascieri and Liang, 1983; Viger et al., 1983). However, the labeling of the SP receptor in rat brain membranes with $\left[{ }^{3} \mathrm{H}\right] \mathrm{SP}$ has been hampered by high nonspecific binding (Hanley et al., 1980) and by the lack of correlation between the relative potency of some peptides to compete with $\left[{ }^{3} \mathrm{H}\right] \mathrm{SP}$ and their relative potency to produce neuronal depolarization. Nevertheless, $\left[{ }^{3} \mathrm{H}\right] \mathrm{SP}$ has been used successfully in labeling the SP receptor in rat brain slices by autoradiography (Quirion ct al., 1983a).

We have used $\left.{ }^{3} \mathrm{H}\right] \mathrm{PHY}$ to label the $\mathrm{SP}$ receptor in rat brain membranes because $\mathrm{PHY}$ and $\mathrm{SP}$ are generally considered to act on the same receptor. Cross-desensitization and inactivation of the $\mathrm{SP}$ receptor on the guinea pig ileum have indicated that $\mathrm{SP}$ and $\mathrm{PHY}$ interact with the same receptor (Lee et al., 1982; Lirl and Musacchio, 1983). Furthermore, analysis of the binding of $\left[{ }^{3} \mathrm{H}\right] \mathrm{SP}$ and $\left[{ }^{3} \mathrm{H}\right] \mathrm{PHY}$ to rat submaxillary gland membranes demonstrated that both peptides interact with the same binding site (Bahouth et al., 1985). We demonstrate in this paper that $\left[{ }^{3} \mathrm{H}\right] \mathrm{PHY}$ binds with high specificity to rat brain membranes in the presence of appropriate peptidase inhibitors and monovalent and divalent cations. The binding is saturable, reversible, and inhibitcd compctitively by SP and other peptides. The low nonspecific binding of $\left[{ }^{3} \mathrm{HI} \mathrm{PHY}\right.$ makes this label one of the ligands of choice to characterize the SP.P receptor in the central nervous system and in peripheral tissues.

\footnotetext{
${ }^{4}$ We followed the uniform tachykinin nomenclature recommended by the satellite symposium to the 9th IUPHAR International Congress of Pharmacology on "SP: Metabolism and Biological Actions," which is the following neurokinin $A(N K A)$, is also known as neurokinin alpha or neuromedin $L$ or substance $K(S K)$. Neurukinin $B(N K B)$ is also known as neurokinin beta or neuromedin $K$.
} 


\section{Materials and Methods}

Materials. Peptides were purchased from Peninsula Laboratories (Belmont, CA). Polyethylenimine (PEI). HEPES, bacitracin, chymostatin, choline chloride, bovine serum albumin (BSA), soybean trypsin inhibitor, trypsin, GDP, GTP, $5^{\prime}$-guanylimidodiphosphate (Gpp(NH)p), $N$-ethylmaleimide (NEM), $p$-chloromercuribenzoate (PCMB), and dithiothreitol (DTT) were all obtained from Sigma Chemical Co. (St Louis, MO). GF/B glass fiber filters were purchased from Whatman L.td. (Maidstone, England). Samples were filtered with the multiple cell harvester (M-24) from Brandel Biomedical Research and Development Labs. (Gaithersburg, MD)

Synthesis, storage, and purity of $\left[{ }^{3} \mathrm{H}\right] \mathrm{PHY}$. $\left[{ }^{3} \mathrm{H}\right] \mathrm{PHY}$ was prepared from HHY (Cambridge Research Biochemicals, Cambridge, England) by catalytic tritiation of iodinated PHY in which the methionine residue was temporarily protected as the sulfoxide. The product was isolated by semi-preparative high performance liquid chromatography (HPLC) and had a satisfactory amino acid analysis after acidic hydrolysis. The specific activity was $30.4 \pm$ $2.3 \mathrm{Ci} \mathrm{mmol}^{-1}$ and the radiochemical purity was $99 \%$ inclusive of not more than $1 \%$ of the sulfoxide. The purity of $\left[{ }^{3} \mathrm{H}\right] \mathrm{PHY}$ was periodically checked by reverse phase HPLC as described for SP (Huidobro-Toro et al., 1982).

$\left[{ }^{3} \mathrm{H}\right] \mathrm{PHY}$ was diluted to $10 \mu \mathrm{M}$ with $10 \mathrm{~mm}$ acetic acid, and small aliquots were stored in cryotubes in liquid nitrogen. The stock was diluted to 1.5 to $2 \mu \mathrm{M}$ in $5 \%$ ethanol, $1 \mathrm{~mm}$ mercaptoethanol and stored at $-20^{\circ} \mathrm{C}$ under nitrogen. Under these conditions, the decomposition of $\left.{ }^{3} \mathrm{H}\right] \mathrm{PHY}$ was less than $5 \% /$ month.

Tissue preparation. Male Sprague-Dawley rats (200 to $250 \mathrm{gm}$ ) were killed by decapitation. The brains without the cerebella were homogenized in 50 vol $(w / v)$ of $20 \mathrm{~mm}$ HEPES, $\mathrm{pH} 7.4$, at $4^{\circ} \mathrm{C}$ using a Brinkman Polytron tissue disruptor (speed 8 , for $30 \mathrm{sec}$ ), and the homogenate was centrifuged at 900 $\times g$ for $10 \mathrm{~min}$. The low speed pellet was discarded and the supernatant was centrifuged at $34,000 \times g$ for $30 \mathrm{~min}$ at $4^{\circ} \mathrm{C}$. The resulting pellet was resuspended in 11.5 vol of $0.125 \mathrm{M}$ sodium sulfate, $20 \mathrm{mM}$ HEPES $(\mathrm{pH} 7.4)$ at $4^{\circ} \mathrm{C}$. Chymostatin dissolved in dimethylsulfoxide (DMSO; $20 \mathrm{mg} / \mathrm{ml}$ ), and bacitracin in water $(50 \mathrm{mg} / \mathrm{ml})$ were added $30 \mathrm{~min}$ before the initiation of the binding assay. The final concentration of DMSO did not affect the binding of $\left[{ }^{3} \mathrm{H}\right] \mathrm{PHY}$. All peptidase inhibitors and peptides were stored at $-20^{\circ} \mathrm{C}$ in small aliquots.

[MIJPHY binding assay. The binding was initiated by the addition of 0.25 $\mathrm{ml}$ of the membrane preparation to a final volume of $0.5 \mathrm{ml}$. The final composition of the incubation medium consisted of $0.125 \mathrm{M}$ sodium sulfate, $2.5 \mathrm{mM} \mathrm{MnCl}_{2}, 20 \mathrm{mM}$ HEPES, pH 7.4, $0.3 \mathrm{mg} / \mathrm{ml}$ of bacitracin, and 0.05 $\mathrm{mg} / \mathrm{ml}$ of chymostatin. The samples were incubated at $20^{\circ} \mathrm{C}$ in a shaking water bath, and after 30 min they were filtered through Whatman GF/B filters presoaked in $0.05 \% \mathrm{PEl}$ in water at room temperature for 4 to $6 \mathrm{hr}$. The filters were washed prior to the sample application with $5 \mathrm{ml}$ of wash buffer (100 mm choline chloride, 0.1\% BSA, and $50 \mathrm{~mm}$ sodium phosphate, $\mathrm{pH} 7.4$, at $4^{\circ} \mathrm{C}$ ). After the sample application, the filters were rapidly washed three times with $5 \mathrm{ml}$ of the same ice-cold wash buffer. The bound $\left[{ }^{3} \mathrm{H}\right] \mathrm{PHY}$ was determined by placing the filters in vials containing $1 \mathrm{ml}$ of NCS tissue solubilizer (Amersham Corporation, Arlington Heights, IL). The vials were shaken for $30 \mathrm{~min}$, and then $10 \mathrm{ml}$ of toluene scintillation fluid $(0.4 \%, 2,5$ diphenyloxazole and $0.02 \%$ p-bis[2-(5-phenyloxazolyl)]benzene werc added. Tritium was determined in a Beckman LS-230 liquid scintillation spectrometer at $30 \%$ efficiency. The proteins were determined by the method of Lowry et al. (1951) as modified by Peterson (1977), and the contribution of bacitracin and chymostatin to the total protein was subtracted. All labeled and unlabeled peptides were diluted in BSA-coated polypropylene Eppendorf tubes. For this purpose, the tubes were filled with ice-cold $0.1 \%$ ultrapure albumin for 6 hr at $4^{\circ} \mathrm{C}$, and the contents were emptied by suction, air dried, and stored at room temperature until use. For saturation experiments, increasing concentrations of [ $\left.{ }^{3} \mathrm{H}\right] \mathrm{PHY}$ (1 to $30 \mathrm{~nm}$ ) were added with the nonspecific binding defined as $\left[{ }^{3} \mathrm{H}\right] \mathrm{PHY}$ bound in the presence of $1 \mu \mathrm{M} \mathrm{PHY}$

The effect of pretreatment with ions on $\left[{ }^{3} \mathrm{H}\right] \mathrm{PHY}$ binding to rat brain membranes was analyzed as follows. (a) To study whether the effects of sodium sulfate on $\left[{ }^{3} \mathrm{H}\right] \mathrm{PHY}$ binding persist after its removal, the membranes were incubated in $0.125 \mathrm{M} \mathrm{Na}_{2} \mathrm{SO}_{4}$ for $1 \mathrm{hr}$ at $4^{\circ} \mathrm{C}$, then centrifuged at $100,000 \times g$, and the binding assay was carried out in the membranes resuspended in $20 \mathrm{mM}$ HEPES ( $\mathrm{pH} 7.4$ ). (b) The tissue was incubated in $0.125 \mathrm{M}$ sodium sulfate for $1 \mathrm{hr}$ at $4^{\circ} \mathrm{C}$, then centrifuged, and the pellet was resuspended in the same incubation medium.

Preparation of subcellular fractions. Rat brain membranes were prepared by the method of De Robertis et al. (1962). Brain without the cerebellum was homogenized in $10 \mathrm{vol}$ of $0.32 \mathrm{~m}$ sucrose using a Teflon-glass homogenizer. The homogenate was centrifuged for $15 \mathrm{~min}$ at $1,000 \times \mathrm{g}$ and the nuclear pellet $\left(P_{1}\right)$ was washed once with $0.32 \mathrm{M}$ sucrose. The resulting supernatant was centrifuged at $17,000 \times g$ for 20 min to yield the crude mitochondrial pellet $\left(P_{2}\right)$, that was washed once by resuspending in $0.32 \mathrm{M}$ sucrose and centrifuging at $17,000 \times g$ for $15 \mathrm{~min}$. The crude $P_{2}$ was osmotically shocked in 5 vol of $5 \mathrm{~mm}$ HEPES, pH 8.4, for $1 \mathrm{hr}$ at $4^{\circ} \mathrm{C}$, then centrifuged at 100,000 $\times g$ for $10 \mathrm{~min}$. The pellet was resuspended in $0.32 \mathrm{M}$ sucrose and applied to a discontinous sucrose gradient consisting of successive 6-ml layers of $0.4,0.6,0.8,1.0$, and $1.2 \mathrm{M}$ sucrose. After centrifugation at $63,580 \times g$ for 90 min in a Beckman SW-27 rotor, each band was separated, diluted with 5 mM HEPES, and centrifuged at $100,000 \times g$ for $30 \mathrm{~min}$. The supernatant of the crude mitochondrial pellet was centrifuged at $100,000 \times g$ for $60 \mathrm{~min}$ to obtain the microsomal pellet $\left(\mathrm{F}_{3}\right)$. All of the fractions were resuspended in 10 vol of $0.125 \mathrm{M}$ sodium sulfate, $20 \mathrm{~mm}$ HEPES (pH 7.4) and assayed for specific $\left[{ }^{3} \mathrm{H}\right] \mathrm{PHY}$ binding.

Calculation and data preparation. The data from each saturation with $\left[{ }^{3} \mathrm{H}\right]$ $\mathrm{PHY}$ and competition experiment with either PHY or the other unlabeled peptides were entered in the appropriate subroutine of the Equilibrium Binding Data Analysis program, EBDA (McPherson, 1983). This program is designed to process raw data from radioligand binding experiments into a form suitable for use by the nonlinear least square fitting program, SCAFIT (Munson and Rodbard, 1980), which was used for the analysis of saturation and competition data. The kinetic data were analyzed by the computer program ESTRIP (Brown and Manno, 1978). The CBDA, SCAГIT, and ESTRIP programs were adapted to the IBM-PC computer and supplied by G. A. McPherson, Victorian College of Pharmacy (381 Royal Pde, Parkville, Victoria 3052, Australia).

\section{Results}

\section{General Characteristics of $\left[{ }^{3} \mathrm{H}\right] \mathrm{PHY}$ binding}

Inhibition of $\left[{ }^{3} \mathrm{H}\right] \mathrm{PHY}$ degradation. Addition of bacitracin $(0.3 \mathrm{mg} /$ $\mathrm{ml})$ and chymostatin $(0.05 \mathrm{mg} / \mathrm{ml})$ resulted in a $94 \%$ recovery of the $\left[{ }^{3} \mathrm{H}\right] \mathrm{PHY}$ after $30 \mathrm{~min}$ of incubation with tissue at $20^{\circ} \mathrm{C}$ as determined by HPLC. This is in contrast with rat submaxillary gland membranes which, in addition, required sequential pretreatment with $0.1 \mathrm{mM}$ TLCK-TPCK to block the degradation of $\left[{ }^{3} \mathrm{H}\right] \mathrm{SP}$ and $\left[{ }^{3} \mathrm{H}\right] \mathrm{PHY}$.

Effect of homogenization in sucrose or HEPES. We compared the specific binding in the tissue homogenized in $20 \mathrm{mM}$ HEPES $(\mathrm{pH}$ 7.4) or $0.32 \mathrm{M}$ sucrose, $20 \mathrm{~mm}$ HEPES (pH 7.4), and the specific binding was 29.9 and $16.0 \mathrm{fmol} / \mathrm{mg}$ of protein, respectively. Therefore, subsequent binding experiments were carried out by homogenizing the brain in 20 mM HEPES as outlined under "Materials and Methods."

Effect of temperature. The specific binding of $\left[{ }^{3} \mathrm{H}\right] \mathrm{PHY}$ to rat brain membranes is temperature sensitive. A time course analysis (in the absence of $\mathrm{Mn}^{2+}$ ) revealed a more rapid initial binding at $37^{\circ} \mathrm{C}$ than

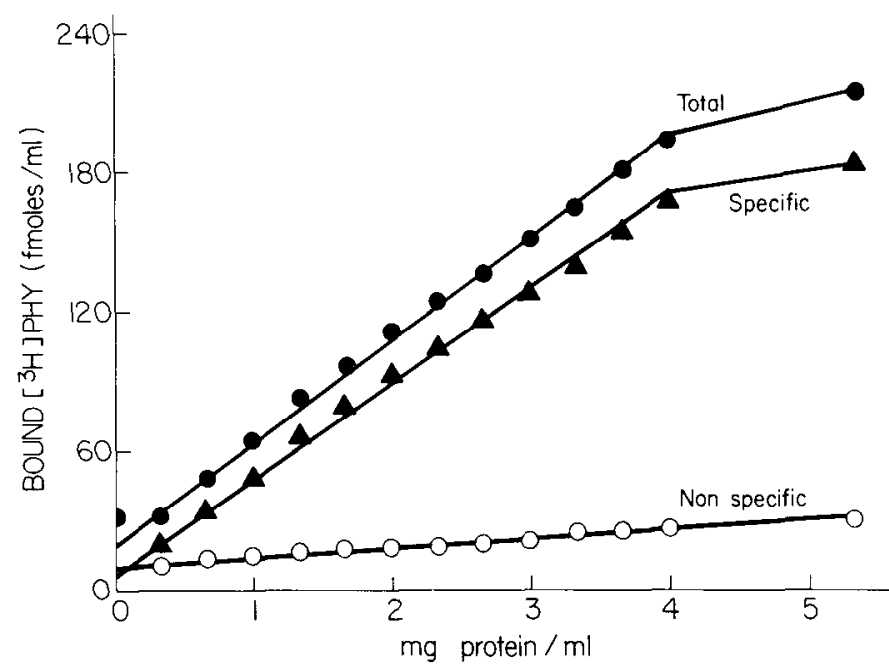

Figure 1. $\left[{ }^{3} \mathrm{H}\right] \mathrm{PHY}$ binding al various lissue concentrations. Different concentrations of rat brain membranes, prepared as described under "Materials and Methods," were incubated with $4 \mathrm{nM}\left[{ }^{3} \mathrm{H}\right] \mathrm{PHY}$ in $0.125 \mathrm{M} \mathrm{Na}_{2} \mathrm{SO}_{4}$, $2.5 \mathrm{mM} \mathrm{MnCl}_{2}, 20 \mathrm{~mm}$ HEPES (pH 7.4) for $30 \mathrm{~min}$ at $20^{\circ} \mathrm{C}$. Nonspecific binding $(\mathrm{O})$ was determined by co-incubating the radioactive ligand with 1 $\mu \mathrm{M}$ PHY. Specific $\left[{ }^{3} \mathrm{H}\right] \mathrm{PHY}$ bound $(\boldsymbol{\Delta})$ was calculated by subtracting nonspecific binding from total binding (O). The values are the mean of triplicate determinations of an experiment replicated twice. 
TABLE ।

Effect of trypsin on specific $\left[{ }^{3} \mathrm{H}\right] \mathrm{PHY}$ binding

The $900 \times g$ supernatant of the rat brain homogenate was preincubated for $30 \mathrm{~min}$ at $20^{\circ} \mathrm{C}$ with or without difterent concentrations of trypsin and/or soybean trypsin inhibitor as indicated. Soybean trypsin inhibitor was added to the trypsin-containing samples after $30 \mathrm{~min}$, and the incubation was continued for $5 \mathrm{~min}$. The samples were then cooled on ice and centrifuged at $34,000 \times g$ for $30 \mathrm{~min}$. The pellets were resuspended in the assay buffer and membrane aliquots were assayed for $\left[{ }^{3} \mathrm{H}\right] \mathrm{PHY}$ binding. Values are the mean of triplicate samples of a single experiment replicated once.

\begin{tabular}{|c|c|c|}
\hline $\begin{array}{l}\text { Trypsin } \\
(\mu \mathrm{g} / \mathrm{ml})\end{array}$ & $\begin{array}{l}\text { Trypsin Inhibitor } \\
(\mu \mathrm{g} / \mathrm{ml})\end{array}$ & $\begin{array}{c}{\left[{ }^{3} \mathrm{H}\right] \mathrm{PHY} \text { Bound }} \\
\text { (\% of control) }\end{array}$ \\
\hline 30 & & 26.8 \\
\hline 30 & 90 & 44.7 \\
\hline 100 & & 20.8 \\
\hline 100 & 300 & 51.7 \\
\hline 300 & & 12.3 \\
\hline 300 & 600 & 48.8 \\
\hline
\end{tabular}

at $20^{\circ} \mathrm{C}$. However, after 30 min of incubation, the binding of $\left[{ }^{3} \mathrm{H}\right]$ $\mathrm{PHY}$ was $16.1 \mathrm{fmol} / \mathrm{mg}$ of protein at $20^{\circ} \mathrm{C}$ and comparatively less at $37^{\circ} \mathrm{C}(66 \%)$. The specific binding in the tissue incubated at $4^{\circ} \mathrm{C}$ for 30 min was only $25 \%$ of that at $20^{\circ} \mathrm{C}$. Specific [ $\left.{ }^{3} \mathrm{H}\right] \mathrm{PHY}$ binding was abolished when the tissue was preincubated at $70^{\circ} \mathrm{C}$ for $5 \mathrm{~min}$. It is noteworthy that the nonspecific binding increased markedly with the heat treatment.

Effect of $\mathrm{pH}$. The $\mathrm{pH}$ profile for specific $\left[{ }^{3} \mathrm{H}\right] \mathrm{PHY}$ binding at $20^{\circ} \mathrm{C}$ demonstrated that the binding was maximal betwcen $\mathrm{pH} 8.0$ and 9.0. A gradual decrease was observed above $\mathrm{pH} 9.0$ and a sharp decrease was observed below pH 8.0. However, we decided to carry out the binding assay at the physiological pH of 7.4.

Tissue linearity of $\left[{ }^{3} \mathrm{H}\right] \mathrm{PHY}$ binding. The total and the specific binding of $\left[{ }^{3} \mathrm{H}\right] \mathrm{PHY}$ increased linearly with protein concentrations up to $4.0 \mathrm{mg} / \mathrm{ml}$ (Fig. 1). Under these conditions, the [ $\left.{ }^{3} \mathrm{H}\right] \mathrm{PHY}$ specific binding was about $85 \%$ of the total binding observed, and $3.2 \mathrm{mg} /$ $\mathrm{ml}$ of protein was routinely used.

Effect of trypsin. Trypsin treatment of rat brain membranes resulted in a $75 \%$ loss of specific $\left[{ }^{3} \mathrm{H}\right] \mathrm{PHY}$ binding. These effects were dose dependent, and they were partially antagonized by the soybean trypsin inhibitor (Table I).

Effect of sulfhydryl reagents. Preincubation of the membranes with NEM or PCMB resulted in a dose-dependent loss of PHYbinding sites with an $I_{50}$ of 1.0 and $0.15 \mathrm{nM}$, respectively (Fig. 2). The action of NEM was more pronounced when incubated with the membranes at $37^{\circ} \mathrm{C}$ than at $4^{\circ} \mathrm{C}$. The inhibitory action of NEM on $\left[{ }^{3} \mathrm{H}\right] \mathrm{PHY}$ binding could be prevented by co-incubation with reduced glutathione or DTT but could not be reversed either by washing or by an additional incubation with DTT

\section{Subcellular localization of $\left.{ }^{3} \mathrm{H}\right] \mathrm{PHY}$ binding sites}

Subcellular fractions prepared by difterential and sucrose density gradient centrifugation as described under "Materials and Methods" were tested for $\left.{ }^{3} \mathrm{H}\right] \mathrm{PHY}$ binding. Initial experiments demonstrated that the "nuclear" fraction (1,000 $\times g$ sediment) contained very low specific activity binding ( $5.4 \mathrm{fmol} / \mathrm{mg}$ of protein), and the "mitochondrial" fraction (17,000 $\times g$ sediment), which contains the synaptosomes, had the highest specific activity, $35.5 \mathrm{fmol} / \mathrm{mg}$. To determine with more precision the site of the $\left[{ }^{3} \mathrm{H}\right] \mathrm{PHY}$ binding in the $17,000 \times$ $g$ sediment, this fraction was further fractioned as described under "Materials and Methods." A significant amount of [ $\left.{ }^{3} \mathrm{H}\right] \mathrm{PHY}$ binding was observed in all of the fractions, but the highest specific activity and binding were found in the "microsomal" fraction followed by the synaptosomal membrane fractions (Table II).

\section{Kinetics of [ $\left.{ }^{3} \mathrm{H}\right] \mathrm{PHY}$ binding}

The association rate of $\left[{ }^{3} \mathrm{H}\right] \mathrm{PHY}$ to rat brain membranes suspended in $0.125 \mathrm{M} \mathrm{Na}_{2} \mathrm{SO}_{4}, 2.5 \mathrm{~mm} \mathrm{MnCl}_{2}, 20 \mathrm{~mm}$ HEPES (pH 7.4)

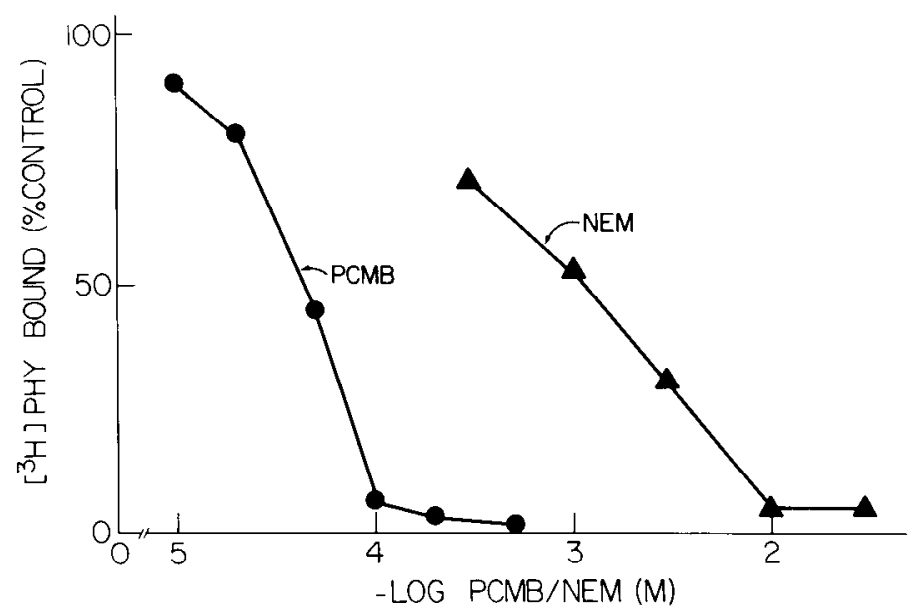

Figure 2. Effect of sulfhydryl reagents on $\left[{ }^{3} \mathrm{H}\right] \mathrm{PHY}$ binding. Rat brain membranes were incubated in $20 \mathrm{~mm}$ HEPES ( $\mathrm{pH} 7.4$ ) with increasing concentrations of either NEM $\left(30 \mathrm{~min}, 37^{\circ} \mathrm{C}\right)$ or PCMB $\left(15 \mathrm{~min}, 30^{\circ} \mathrm{C}\right)$. Equimolar amounts of DTT were added to the NEM and the corresponding control samples. All of the samples were cooled immediately on ice and centrifuged at $34,000 \times g$ for $30 \mathrm{~min}$. After washing three times, the membranes were suspended in the incubation buffer and assayed for $\left[{ }^{3} \mathrm{H}\right]$ $\mathrm{PHY}$ binding. The data are given as percentage of binding of control membranes. Values are the mean of triplicate determinations of an individual experiment which was replicated once

TABLE ॥

Subcellular distribution of $\left[{ }^{3} \mathrm{H}\right] \mathrm{PHY}$ binding in rat brain

Subcellular fractions were prepared as described under "Materials and Methods," and the specific binding of [3/ I]PI IY (3.65 nM) was determined in each fraction. Nonspecific binding was determined in the presence of $1 \mu \mathrm{M}$ PHY, Results are the mean of triplicate determinations of a single experiment.

\begin{tabular}{|c|c|c|}
\hline \multirow[t]{2}{*}{ Sucrose Fractions $(0.32 \mathrm{M})$} & \multicolumn{2}{|c|}{ Specific Binding } \\
\hline & $\begin{array}{l}\text { fmol/mg of } \\
\text { protein }\end{array}$ & $\mathrm{fmol} / \mathrm{gm}$ of wet weight $\mathrm{t}^{\mathrm{a}}$ \\
\hline Nuclear $\left(1,000 \times g\right.$ pellet, $\left.P_{1}\right)$ & $18.9(58)^{b}$ & 141.6 \\
\hline Lysed $\mathrm{P}_{2}$ subfractions & & \\
\hline Synaptosomal membranes $I^{c}$ & $29.0(67)$ & 109.2 \\
\hline Synaptosomal membranes $\|^{d}$ & $33.4(78)$ & 41.8 \\
\hline Disrupted synaptosomes ${ }^{e}$ & $16.7(67)$ & 16.8 \\
\hline Mitochondria ${ }^{f}$ & $6.9(48)$ & 17.4 \\
\hline Microsomal $\left(100,000 \times g\right.$ pellet $\left.P_{3}\right)$ & $47.5(86)$ & 234.6 \\
\hline
\end{tabular}

${ }^{a}\left[{ }^{3} \mathrm{H}\right] \mathrm{PHY}$ specific binding per gram of brain wet weight.

${ }^{\circ}$ Data in parentheses are the percentage of specific $\left[{ }^{3} \mathrm{H}\right] \mathrm{PHY}$ bound.

' Sucrose concentration, 0.6 to $0.8 \mathrm{M}$.

${ }^{\circ}$ Sucrose concentration, 0.8 to $1.0 \mathrm{M}$.

${ }^{\theta}$ Sucrose concentration, 1.0 to $1.2 \mathrm{M}$.

${ }^{t}$ The $63,580 \times g$ pellet from the lysed $P_{2}$ fraction.

is shown in Figure $3 A$. The specific binding reached equilibrium between 20 and $30 \mathrm{~min}$. Under these conditions, the nonspecific binding was already maximal at $2 \mathrm{~min}$. Since the total binding of $\left[{ }^{3} \mathrm{H}\right]$ $\mathrm{PHY}$ was less than $5 \%$ of the total radiolabeled ligand added, and no degradation of the peptide occurred within this period, the data obtained from the specific binding were linearized according to the pseudo-first order reaction (Kitabgi et al., 1977). A plot of In ( $B_{\text {eq }}$ $B_{\text {eq }}-B$ ) versus time, where $B$ is the amount of specific $\left[{ }^{3} \mathrm{H}\right] \mathrm{PHY}$ bound at time $t$, and $B_{\text {eq }}$ is the amount bound at equilibrium, is represented in Figure $3 A$, inset. From these results, the $K_{\mathrm{obs}}$, which is the observed forward rate constant of the pseudo-first-order reaction, was $0.107 \mathrm{~min}^{-1}$.

Specific binding was reversible, because rapid dissociation of the ligand was observed when $1 \mu \mathrm{M}$ unlabeled PHY was added after equilibrium had been reached (Fig. $3 B$ ). The dissociation data were linearized by plotting in $B / B_{0}$ versus time. The slope, which is the dissociation rate constant $\left(K_{-1}\right)$, was $9.94 \times 10^{-3} \mathrm{sec}^{-1}$. From the 

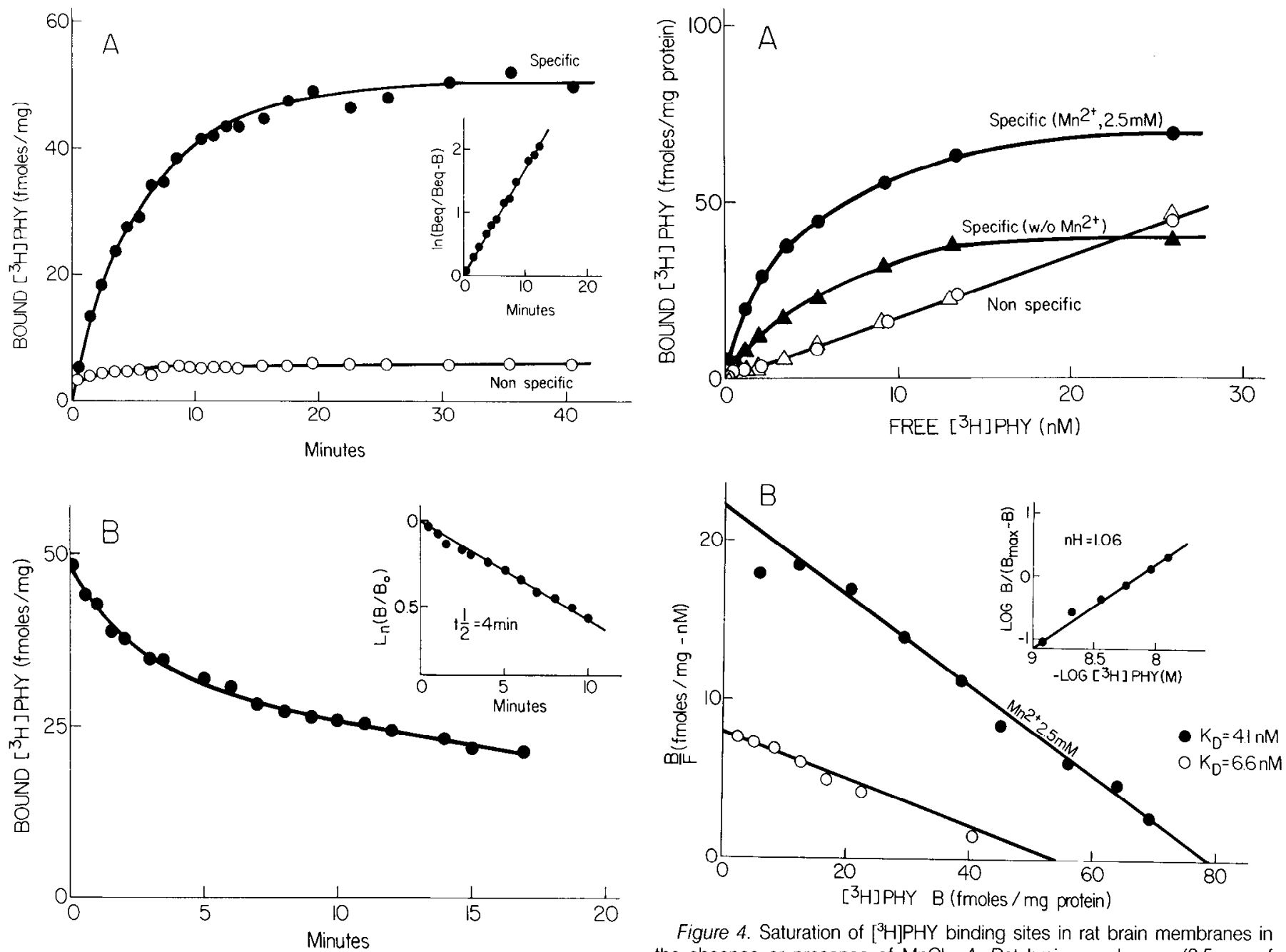

Figure 4. Saturation of $\left[{ }^{3} \mathrm{H}\right] \mathrm{PHY}$ binding sites in rat brain membranes in the absence or presence of $\mathrm{MnCl}_{2}$. A, Rat brain membranes $(2.5 \mathrm{mg}$ of protein/ml) suspended in $0.125 \mathrm{M} \mathrm{Na}_{2} \mathrm{SO}_{4}, 20 \mathrm{mM}$ HEPES $(\mathrm{pH} 7.4)$ were incubated with increasing concentrations of $\left[{ }^{3} \mathrm{H}\right] \mathrm{PHY}(0.4$ to $39 \mathrm{~nm})$. Specific binding in the absence $(\boldsymbol{\Lambda})$ or presence $(\boldsymbol{O})$ of $2.5 \mathrm{mM} \mathrm{MnCl}_{2}$ represents the difference between the total and the nonspecific $\left[{ }^{3} \mathrm{H}\right] \mathrm{PHY}$ binding $(\triangle, O) . B$, Scatchard analysis of specific $\left[{ }^{3} \mathrm{H}\right] \mathrm{PHY}$ binding of a single experiment calculated by the weighed least square fitting program LIGAND. The averages of four replicate experiments were the following: $K_{D}=6.3 \pm 0.7 \mathrm{nM}$ and $B_{\max }$ $=55.3 \pm 1.6 \mathrm{fmol} / \mathrm{mg}$ of protein in the absence of $\mathrm{MnCl}_{2}$, and $K_{\mathrm{D}}=3.7 \pm$ $0.4 \mathrm{nM}$ and $B_{\max }=74.2 \pm 1.2 \mathrm{fmol} / \mathrm{mg}$ of protein in the presence of $2.5 \mathrm{mM}$ $\mathrm{MnCl}_{2}$. Inset, Hill plot in the presence of $\mathrm{MnCl}_{2}$. The Hill coefficient in the absence of divalent cations was also unity. order equation for association. The experiment was replicated once. $B$, Dissociation of specific $\left[{ }^{3} \mathrm{H}\right] \mathrm{PHY}$ binding. $\left[{ }^{3} \mathrm{H}\right] \mathrm{PHY}$ (4 nM) was incubated with the membrane preparations at $20^{\circ} \mathrm{C}$ in a constantly stirred polypropylene beaker. After $30 \mathrm{~min}$, an aliquot $(0.5 \mathrm{ml})$ was filtered through Whatman GF/ $\mathrm{B}$ filter and total $\left[{ }^{3} \mathrm{H}\right] \mathrm{PHY}$ bound $\left(B_{0}\right)$ was determined. Unlabeled $\mathrm{PHY}(1 \mu \mathrm{M})$ in a negligible volume was added to initiate dissociation. The $\left[{ }^{3} \mathrm{H}\right] \mathrm{PHY}$ that remained specifically bound $(B)$ was measured by filtration at the times indicated on the abscissa. The nonspecific binding, which has been subtracted from each point, was determined at each interval in a simultaneous experiment in which unlabeled $\mathrm{PHY}(1 \mu \mathrm{M})$ was added at the beginning of the incubation. Inset, Linearization of the dissociation curve by the first-order rate equation for calculation of the dissociation rate constant. The experiment was replicated once.

slope of the pseudo-first order association reaction and $K_{-1}$, the association rate constant $\left(K_{+1}\right)$ was calculated to be $2.42 \times 10^{7} \mathrm{M}^{-1}$ $\mathrm{sec}^{-1}$. Using the equation $K_{\mathrm{D}}=K_{-1} / K_{+1}$, an equilibrium dissociation constant of $4.41 \mathrm{nM}$ was obtained which is in good agreement with the $K_{\mathrm{D}}$ of $3.66 \pm 0.36 \mathrm{nM}$ determined by saturation Scatchard analysis in the presence of $2.5 \mathrm{mM} \mathrm{MnCl}_{2}$.

\section{Equilibrium binding studies}

Increasing concentrations of [ $\left.{ }^{3} \mathrm{H}\right] \mathrm{PHY}(0.4$ to $30 \mathrm{nM})$ were added to rat brain membranes suspended in $0.125 \mathrm{M} \mathrm{Na}_{2} \mathrm{SO}_{4}, 20 \mathrm{~mm}$

HEPES, $\mathrm{pH} 7.4$ (without $\mathrm{MnCl}_{2}$ ). The specific binding was saturable and the nonspecific binding increased linearly with the added concentration of the labeled ligand. The half-maximal $\left[{ }^{3} \mathrm{H}\right] \mathrm{PHY}$ specific binding was achieved at about $5.4 \mathrm{~nm}\left[{ }^{3} \mathrm{H}\right] \mathrm{PHY}$ (Fig. 4A).

Scatchard plots were linear, indicating a single class of binding sites. The $K_{\mathrm{D}}$ and the $B_{\max }$ were $6.3 \pm 0.73 \mathrm{nM}$ and $55.3 \pm 1.64$ $\mathrm{fmol} / \mathrm{mg}$ of protein, respectively (Fig. $4 B$ ). The Hill plot of the data had a slope $n_{11}=1.03 \pm 0.12$, and the Hofstee plots were linear, indicating that the ligand was bound to a single population of noninteracting sites.

\section{Effect of monovalent cations}

Incubation of rat brain membranes in $20 \mathrm{~mm}$ HEPES with $2.6 \mathrm{nM}$ $\left[{ }^{3} \mathrm{H}\right] \mathrm{PHY}$ without the addition of other ions resulted in negligible specific $\left[{ }^{3} \mathrm{H}\right] \mathrm{PHY}$ binding: $1.1 \mathrm{fmol} / \mathrm{mg}$ of protein. The specifically bound $l^{3} \mathrm{H} J \mathrm{PHY}$ increased dramatically when monovalent cations were included in the incubation medium (Table III). The binding of $\left[{ }^{3} \mathrm{H}\right] \mathrm{PHY}$ in the presence of monovalent cations is dependent on the ionic strength $(\mu)$ of the ions present, not on the ions used. This was 


\section{TABLE IH}

Specific $\left.l^{3} \mathrm{H}\right] \mathrm{PHY}$ binding to rat brain membranes in different ions with 20 mM HEPES

Solutions containing the different salts and $20 \mathrm{~mm}$ HEPES were adjusted to $\mathrm{pH}$ 7.4. Specific $\left[{ }^{3} \mathrm{H}\right] \mathrm{PHY}$ binding was determined using $3.9 \mathrm{nM}\left[{ }^{3} \mathrm{H}\right] \mathrm{PHY}$ Data represent the mean \pm SD of triplicate determinations of individual experiments. The binding in $0.3 \mathrm{M}$ sucrose, $20 \mathrm{~mm}$ HEPES, or $20 \mathrm{~mm}$ HEPES (pH 7.4) was $1.1 \pm 0.15 \mathrm{fmol} / \mathrm{mg}$ of protein.

\begin{tabular}{|c|c|c|}
\hline \multirow{2}{*}{ lons with $20 \mathrm{~mm}$ HEPES } & \multicolumn{2}{|c|}{$\begin{array}{l}\text { Specific }\left[^{3} \mathrm{H} \mathrm{H} \mathrm{PHY} \text { Bound (tmolf }\right. \\
\text { mg of protein) }\end{array}$} \\
\hline & $\mu=0.3^{a}$ & $\mu=0.6^{b}$ \\
\hline \multicolumn{3}{|l|}{ Experiment 1} \\
\hline $\mathrm{NaCl}$ & $14.6 \pm 0.5$ & $10.1 \pm 0.6^{\circ}$ \\
\hline $\mathrm{Na}_{2} \mathrm{SO}_{4}$ & $16.8 \pm 0.2$ & $18.9 \pm 0.3$ \\
\hline $\mathrm{KCl}$ & $13.8 \pm 1.1$ & $9.6 \pm 0.4^{c}$ \\
\hline $\mathrm{K}_{2} \mathrm{SO}_{4}$ & $17.3 \pm 0.9$ & $19.8 \pm 0.3$ \\
\hline $\mathrm{NH}_{4} \mathrm{Cl}$ & $11.2 \pm 0.2$ & $5.3 \pm 0.7^{c}$ \\
\hline$\left(\mathrm{NH}_{4}\right)_{2} \mathrm{SO}_{4}$ & $14.3 \pm 0.5$ & $13.9 \pm 0.7$ \\
\hline $\mathrm{LiCl}$ & $11.5 \pm 0.7$ & $6.8 \pm 0.5^{c}$ \\
\hline $\mathrm{Li}_{2} \mathrm{SO}_{4}$ & $18.6 \pm 0.6$ & $17.2 \pm 0.7$ \\
\hline \multicolumn{3}{|l|}{ Experiment 2} \\
\hline $\mathrm{NaCl}$ & $19.0 \pm 0.5$ & $15.9 \pm 0.7$ \\
\hline $\mathrm{Na}_{2} \mathrm{SO}_{4}$ & $20.1 \pm 0.1$ & $19.2 \pm 0.2$ \\
\hline HCOONa & $22.5 \pm 0.7$ & $20.4 \pm 0.5$ \\
\hline $\begin{array}{l}\mathrm{CH}_{3}- \\
\mathrm{COONa}\end{array}$ & $23.4 \pm 0.5$ & $21.7 \pm 0.8$ \\
\hline
\end{tabular}

${ }^{a}$ The concentration of chlorides, acetate, and formate salts was $0.3 \mathrm{M}$, and that of sulfate salts was $0.1 \mathrm{M}$ at $\mu=0.3$.

${ }^{D}$ The concentration of chlorides, acetate, and formate salts was $0.6 \mathrm{M}$, and that of sulfate salts was $0.2 \mathrm{M}$ at $\mu=0.6$.

${ }^{c} p<0.01$ compared to $\left[{ }^{3} \mathrm{H}\right] \mathrm{PHY}$ binding at $\mu=0.3$.

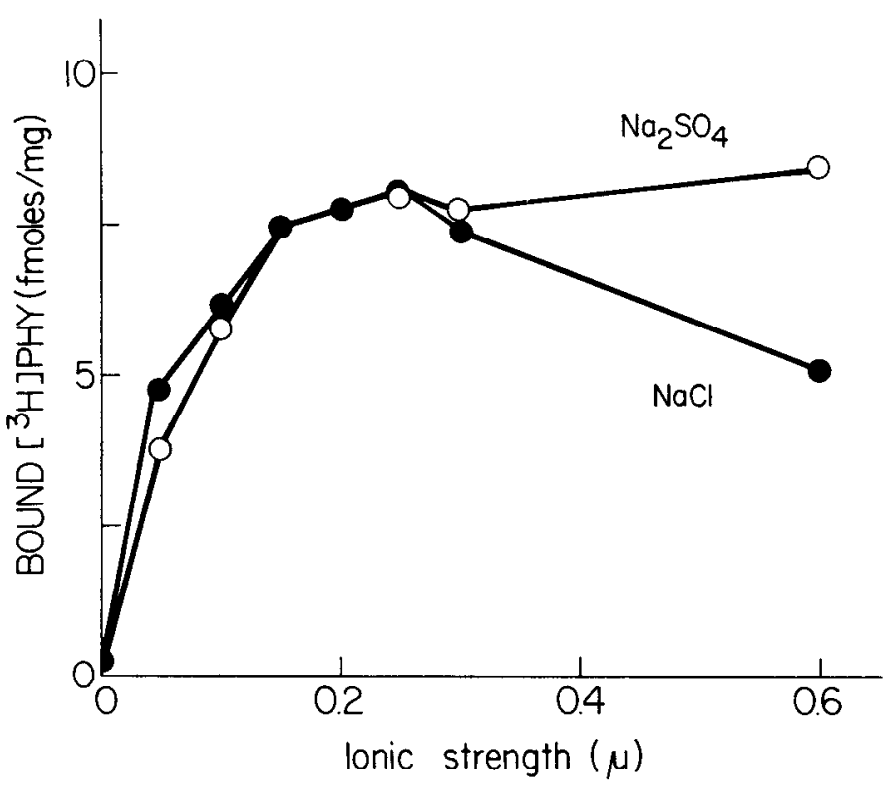

Figure 5. Effect of ionic strength on specific $\left[{ }^{3} \mathrm{H}\right] \mathrm{PHY}$ binding. Rat brain without cerebellum was homogenized in 40 vol of $20 \mathrm{~mm}$ HEPES and centrifuged at $34,000 \times \mathrm{g}$ for $20 \mathrm{~min}$. The pellet was resuspended in $10 \mathrm{vol}$ of $20 \mathrm{~mm}$ HEPES, $\mathrm{pH} 7.4$, incubated with TLCK and TPCK $\left(10^{-4} \mathrm{M}\right)$ for 15 min at $20^{\circ} \mathrm{C}$, cooled for $10 \mathrm{~min}$ on ice, and centrifuged at $34,000 \times g$ for 20 $\mathrm{min}$. The resulting pellet was resuspended in $5 \mathrm{vol}$ of $20 \mathrm{~mm}$ HEPES. Aliquots of the membrane preparations were diluted to $10 \mathrm{vol}$ with different concentrations of $\mathrm{NaCl}$ and $\mathrm{Na}_{2} \mathrm{SO}_{4}$. Specific [ $\left.{ }^{3} \mathrm{H}\right] \mathrm{PHY}$ binding was determined by incubating the membrane preparations with $2.6 \mathrm{nM}\left[{ }^{3} \mathrm{H}\right] \mathrm{PHY}$ for $30 \mathrm{~min}$ at $20^{\circ} \mathrm{C}$ in the presence of different concentrations of salts. Binding of control samples $(0 \mu)$ was measured in $20 \mathrm{~mm}$ HEPES, $\mathrm{pH} 7.4$. The results shown are representatives of two such experiments performed in triplicate. established by determining the specific binding of $\left[{ }^{3} \mathrm{H}\right] \mathrm{PHY}$ in different molar concentrations of $\mathrm{NaCl}$ and $\mathrm{Na}_{2} \mathrm{SO}_{4}(0.025$ to $0.6 \mathrm{M})$. Optimum binding was observed at $0.1 \mathrm{M} \mathrm{Na}_{2} \mathrm{SO}_{4}(\mu=0.3)$ and 0.3 $\mathrm{M} \mathrm{NaCl}(\mu=0.3$, Fig. 5). Binding assays were also performed using other monovalent cation salts in concentrations that provide an ionic strength of either 0.3 or 0.6 . Several salts were studied as described in Table III. Specific [ $\left.{ }^{3} \mathrm{H}\right] \mathrm{PHY}$ binding in both ionic strengths was comparable among the different sulfates and organic anion salts. However, a decrease in the specific binding of $\left[{ }^{3} \mathrm{H}\right] \mathrm{PHY}$ was observed when the ionic strengths of $\mathrm{NaCl}, \mathrm{LiCl}, \mathrm{KCl}$, and $\mathrm{NH}_{4} \mathrm{Cl}$ were increased from 0.3 to 0.6 . This effect is unique to chloride ions, as shown in Table III. Thus, we concluded that when the concentration of chloride is higher than $0.3 \mathrm{M}$, the specific binding of $\left[{ }^{3} \mathrm{H}\right] \mathrm{PHY}$ is inhibited. Subsequent studies on $\left[{ }^{3} \mathrm{H}\right] \mathrm{PHY}$ binding were carried out by suspending the membranes in $0.125 \mathrm{M}$ sodium sulfate, $20 \mathrm{~mm}$ HEPES (pH 7.4) with peptidase inhibitors, and with or without manganese. It is noteworthy that minimal specific binding was observed in either $0.3 \mathrm{M}$ sucrose or $20 \mathrm{~mm}$ HEPES.

Since in $20 \mathrm{~mm}$ HEPES there was no significant binding (Table III), we investigated the effect of pretreatment with ions on the binding of $\left[{ }^{3} \mathrm{H}\right] \mathrm{PHY}$ and found that if the membranes were preincubated in high ionic strength medium, there was binding in $20 \mathrm{~mm}$ HEPES (see "Materials and Methods," condition a: $K_{\mathrm{D}}=6.6 \mathrm{nM}$ and $B_{\max }=$ $57 \mathrm{fmol} / \mathrm{mg}$ of protein), but not as much as if the membranes were resuspended in sodium sulfate (condition $b: K_{D}=4.8 \mathrm{nM}$ and $B_{\max }$ $=75 \mathrm{fmol} / \mathrm{mg}$ of protein) or if they were directly analyzed in the high ionic strength media $\left(K_{\mathrm{D}}=3.2 \mathrm{nM}\right.$ and $B_{\max }=84 \mathrm{fmol} / \mathrm{mg}$ of protein).

\section{Effect of divalent cations}

Divalent cations produced a marked increase on binding of $\left[{ }^{3} \mathrm{H}\right]$ $\mathrm{PHY}$. Manganese was the most potent cation and, at 2 to $5 \mathrm{~mm}$, produced a $65 \%(\rho<0.01)$ increase of specific binding without changing the nonspecific binding (Fig. 4A). Addition of magnesium or calcium elicited a 30 to $40 \%(\rho<0.01)$ increase in specific binding at 2 to $5 \mathrm{~mm}$ concentration.

Scatchard analysis of the saturation with $\left[{ }^{3} \mathrm{H}\right] \mathrm{PHY}$ in the presence of $2.5 \mathrm{mM} \mathrm{MnCl}_{2}$ (average of four experiments) demonstrated about a $35 \%$ increase in the $B_{\max }$ to $74.2 \pm 1.23 \mathrm{fmol} / \mathrm{mg}$ and a decrease in the $K_{D}$ from $6.3 \pm 0.73 \mathrm{~nm}$ to $3.66 \pm 0.36 \mathrm{~nm}$ (Fig. $4 B$ ). Since the addition of manganese resulted in optimal $\left[{ }^{3} \mathrm{H}\right] \mathrm{PHY}$ binding, subsequent binding studies were carried out in the presence of $0.125 \mathrm{M}$ sodium sulfate, $2.5 \mathrm{~mm} \mathrm{MnCl}_{2}, 20 \mathrm{~mm}$ HEPES (pH 7.4).

\section{Effect of guanine nucleotides}

The effect of guanine nucleotides on the binding of $\left[{ }^{3} \mathrm{H}\right] \mathrm{PHY}$ to rat brain membranes was studied in the absence or presence of 2.5 $\mathrm{mM} \mathrm{MnCl}$. In the absence of $\mathrm{MnCl}_{2}, \mathrm{GTP}, \mathrm{GDP}$, and Gpp(NH)p were equally potent in inhibiting the binding of $\left[{ }^{3} \mathrm{H}\right] \mathrm{PHY}$. The maximal inhibition produced was 25 to $30 \%(\rho<0.01)$ at $1 \mathrm{~mm}$, which was the highest concentration tested. in a typical experiment, $4.8 \mathrm{nM}\left[{ }^{3} \mathrm{H}\right]$ $\mathrm{PHY}$ resulted in specific binding of $1520 \mathrm{cpm} / \mathrm{ml}$, and $1 \mathrm{~mm}$ $\mathrm{Gpp}(\mathrm{NH}) \mathrm{p}$ reduced the specifically bound $\left.{ }^{3} \mathrm{H}\right] \mathrm{PHY}$ to $1100 \mathrm{cpm} / \mathrm{ml}$ (Fig. 6). In contrast, in the presence of $2.5 \mathrm{~mm} \mathrm{Mn}^{2+}$ the specifically bound $\left[{ }^{3} \mathrm{H}\right] \mathrm{PHY}$ increased to $3000 \mathrm{cpm} / \mathrm{ml}$, and the addition of $\mathrm{Gpp}(\mathrm{NH}) \mathrm{p}$ markedly reduced the binding in a concentration-dependent manner with an $\mathrm{IC}_{50}$ of $3 \mu \mathrm{M}$. No reliable estimate of the $\mathrm{IC}_{50}$ of other guanine nucleotides could be obtained due to their rapid degradation in the presence of the divalent cation. The addition of $\mathrm{Gpp}(\mathrm{NH}) \mathrm{p}$ inhibited the binding of $\left[{ }^{3} \mathrm{H}\right] \mathrm{PHY}$ in a dose-dependent manner. The maximal inhibition obtained was identical, either in the absence or in the presence of $\mathrm{Mn}^{2+}$ (Fig. 6). Similar effects were observed with GTP and GDP but not with the adenine nucleotides, which required much higher concentrations to elicit partial effects.

\section{Inhibition of specific $\left[{ }^{3} \mathrm{H}\right] \mathrm{PHY}$ binding by related peptides}

The peptides studied inhibited [ $\left.{ }^{3} \mathrm{H}\right] \mathrm{PHY}$ specific binding in a competitive manner. SP, PHY, and $\left[\mathrm{Tyr}^{8}\right]-\mathrm{SP}$ were equipotent in 


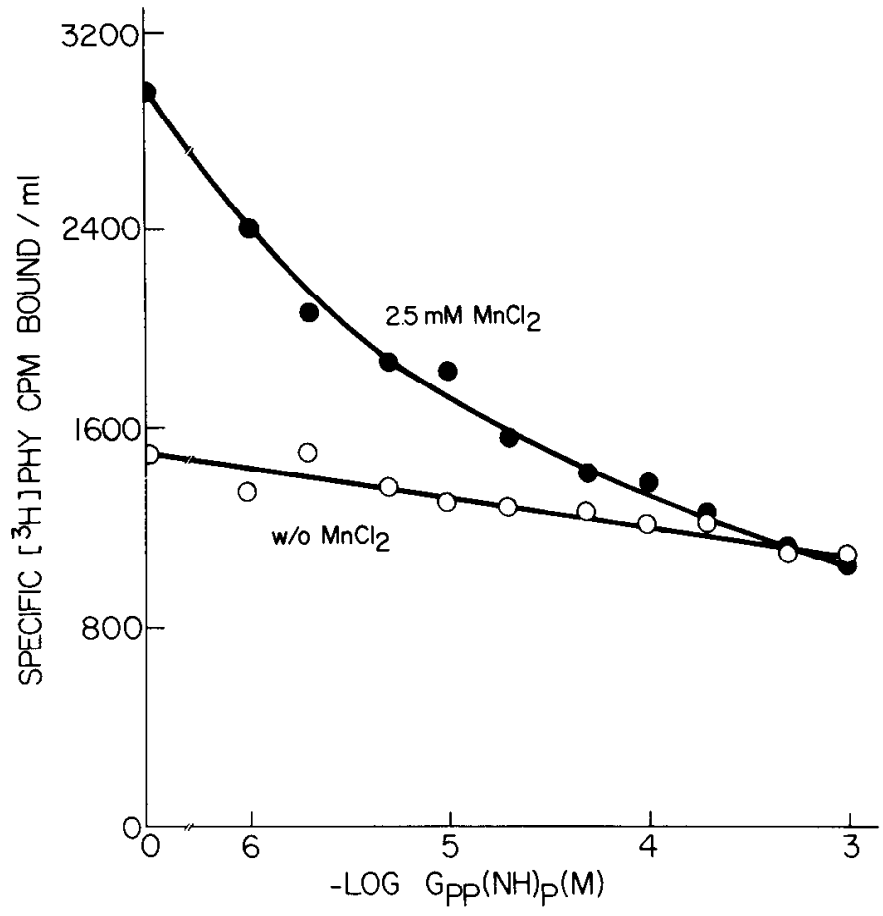

Figure 6. Inhibition of $\left[{ }^{3} \mathrm{H}\right] \mathrm{PHY}$ binding to rat brain membranes by $\mathrm{Gpp}(\mathrm{NH}) \mathrm{p}$ in the absence and presence of $2.5 \mathrm{mM} \mathrm{MnCl}_{2}$. Rat brain membranes suspended in $0.125 \mathrm{M} \mathrm{Na}_{2} \mathrm{SO}_{4}, 20 \mathrm{mM}$ HEPES (pH 7.4) were incubated with $\left[{ }^{3} \mathrm{H}\right] \mathrm{PHY}(4.7 \mathrm{nM})$ and with increasing concentrations of Gpp(NH)p as indicated on the abscissa. Specific $\left[{ }^{3} \mathrm{H}\right] \mathrm{PHY}$ bound $(\mathrm{cpm} / \mathrm{ml})$ in the presence $\left(-\right.$ or absence $(O)$ of $2.5 \mathrm{~mm} \mathrm{MnCl}_{2}$ represents the mean of triplicate determinations of an experiment which was replicated twice.

TABLE IV

Inhibition of $\left[^{3} \mathrm{HIPHY}\right.$ binding to rat brain membranes by several tachykinins and structurally related peptides

Inhibition of the binding of $\left.{ }^{3} \mathrm{H}\right] \mathrm{PHY}(3.0$ to $4.2 \mathrm{nM}$ ) by increasing concentrations of unlabeled peptides. Values are the mean \pm SEM of two or three separate experiments, each in triplicate. The estimates of the $\mathrm{IC}_{50}, K_{1}$, and Hill slope were obtained with the EBDA computer program (McPherson, 1983) after four to six iterations

\begin{tabular}{|c|c|c|c|c|}
\hline Peptide & $\mathrm{IC}_{50}(\mathrm{nM})^{\mathrm{a}}$ & $K_{1}(\mathrm{~nm})^{b}$ & Hill Slope & $\begin{array}{c}\text { Relative } \\
\text { Potencyc }\end{array}$ \\
\hline $\mathrm{PHY}$ & $5.6 \pm 0.2$ & 2.69 & $0.96 \pm 0.3$ & 1.0 \\
\hline SP & $5.9 \pm 0.6$ & 2.73 & $0.98 \pm 0.04$ & 0.985 \\
\hline$\left[T_{y} r^{8}\right]-S P$ & $5.7 \pm 0.4$ & 2.82 & $0.97 \pm 0.07$ & 0.950 \\
\hline $\mathrm{SP}(2-11)$ & $17.2 \pm 1.6$ & 7.78 & $0.96 \pm 0.06$ & 0.346 \\
\hline $\operatorname{SP}(3-11)$ & $31.3 \pm 3.1$ & 16.2 & $0.84 \pm 0.14$ & 0.166 \\
\hline $\operatorname{SP}(4-11)$ & $198 \pm 27$ & 94.4 & $0.98 \pm 0.08$ & 0.028 \\
\hline$\left[p G l u^{1}\right]-S P(5-\uparrow 1)$ & $442 \pm 36$ & 199 & $1.11 \pm 0.07$ & 0.014 \\
\hline$\left[\mathrm{pGl} \mathrm{u}^{1}\right]-\mathrm{SP}(6-11)$ & $696 \pm 74$ & 301 & $1.16 \pm 0.07$ & 0.009 \\
\hline Eledoisin & $1,720 \pm 492$ & 838 & $0.93 \pm 0.07$ & 0.003 \\
\hline Kassinin & $1.328 \pm 164$ & 621 & $0.82 \pm 0.06$ & 0.004 \\
\hline Neurokinin A & $2,066 \pm 134$ & 967 & $0.96 \pm 0.04$ & 0.003 \\
\hline $\operatorname{SP}(7-11)$ & $>30,000$ & $\mathrm{ND}^{\alpha}$ & $\mathrm{ND}$ & $\mathrm{ND}$ \\
\hline
\end{tabular}

${ }^{2}$ Concentration of competing ligand required to inhibit the specific binding by $50 \%$.

"The inhibition constant $\left(K_{1}\right)$ calculated by the EBDA program as described by Cheng and Prusoff (1973)

${ }^{\mathrm{c}}$ Ratio of $\mathrm{PHY} K_{1}$ divided by the $K_{1}$ of the competing peptide.

${ }^{\sigma} \mathrm{ND}$, not determined.

inhibiting the $\left[{ }^{3} \mathrm{H}\right] \mathrm{PHY}$ binding, with an identical $\mathrm{IC}_{50}$ (Fig. 7, Table IV). The affinities of SP(2-11), SP(3-11), and SP(4-11) decreased in inverse proportion to their length. Eledoisin (the SP-E prototype ligand), kassinin, and neurokinin $\mathrm{A}$ (NKA) were less than $1 \%$ as potent as PHY, whereas, $\operatorname{SP}(7-11)$ was inactive. The final estimates
TABLE $V$

Regional distribution of specific $\left[{ }^{3} \mathrm{H}\right] \mathrm{PHY}$ binding in rat brain membranes

Ral brain regions were dissecled and hornogenized in 40 vol of $20 \mathrm{~mm}$ HEPES (pH 7.4). Specific [ $\left.{ }^{3} \mathrm{H}\right] \mathrm{PHY}$ binding was measured in $0.125 \mathrm{M} \mathrm{Na}_{2} \mathrm{SO}_{4}$, $20 \mathrm{~mm}$ HEPES, pH 7.4 (without $\mathrm{MnCl}_{2}$ ), using $5.8 \mathrm{~nm}\left[{ }^{3} \mathrm{H}\right] \mathrm{PHY}$. Values represent the mean of triplicate determinations \pm SD of a single experiment at two different tissue concentrations.

\begin{tabular}{lc}
\hline Region & $\begin{array}{c}\text { Specific }\left[{ }^{3} \mathrm{H}\right] \mathrm{PHY} \text { Bound } \\
\text { (fmol/mg of protein) }\end{array}$ \\
\hline Cerebellum & $3.6 \pm 0.2$ \\
Medulla oblongata & $21.7 \pm 2.2$ \\
Hypothalamus & $36.8 \pm 2.5$ \\
Striatum & $34.9 \pm 1.4$ \\
Midbrain & $25.3 \pm 0.3$ \\
Hippocampus & $30.3 \pm 2.5$ \\
Cortex & $23.8 \pm 0.6$ \\
Olfactory bulb & $73.3 \pm 1.1$
\end{tabular}

of the $\mathrm{IC}_{50}, K_{1}, n_{\mathrm{H}}$, and the rank order of potencies of different peptides calculated from the pooled data of several experiments are shown in Table IV

\section{Regional distribution of ${ }^{3} \mathrm{H} / \mathrm{PHY}$ binding}

A study of different brain regions demonstrated that the binding sites for $\left[{ }^{3} \mathrm{H}\right] \mathrm{PHY}$ were unevenly distributed (Table $\mathrm{V}$ ). The specific binding was highest in the olfactory bulb and lowest in the cerebellum. The densities of PHY-binding sites in medulla oblongata, hypothalamus, striatum, midbrain, hippocampus, and the cortex were similar.

Scalchard arlalysis for the binding of $\left[{ }^{3} \mathrm{H}\right] \mathrm{PHY}$ to the brain without cerebellum (in $0.125 \mathrm{M} \mathrm{Na}_{2} \mathrm{SO}_{4}, 20 \mathrm{mM}$ HEPES without $\mathrm{MnCl}_{2}$ ) demonstrated a $B_{\max }=55.3 \pm 1.6 \mathrm{fmol} / \mathrm{mg}$, with an affinity constant $K_{\mathrm{D}}=6.3 \pm 0.73 \mathrm{nM}$, respectively. The olfactory bulb had a $B_{\max }=$ $102 \mathrm{fmol} / \mathrm{mg}$ and a $K_{\mathrm{D}}=3.2 \mathrm{nM}$. When brain membranes were incubated in the presence of $\mathrm{Mn}^{2+}$ ions, there was an apparent increase in both the receptor number and affinity, with a $B_{\max }=74.2$ $\pm 1.23 \mathrm{fmol} / \mathrm{mg}$ and $K_{\mathrm{D}}=3.66 \pm 0.36 \mathrm{nM}$, respectively.

\section{Discussion}

We used $\left[{ }^{3} \mathrm{H}\right] \mathrm{PHY}$ to study the SP receptor in rat central nervous system because we have previously demonstrated that this ligand interacts specifically with the SP-P receptor of rat salivary gland membranes (Bahouth et al., 1985). The binding of [ $\left.{ }^{3} \mathrm{H}\right] \mathrm{PHY}$ is $\mathrm{pH}$ dependent and temperature sensitive. Heating or preincubation of the membranes with trypsin led to complete inhibition of specific binding, suggesting that the binding site is proteinaceous in nature. The binding was also inhibited by preincubation with NEM and $\mathrm{PCMB}$, indicating that it is also dependent on sulfhydryl groups. $\left[{ }^{3} \mathrm{H}\right]$ $\mathrm{PHY}$ binding to rat brain membranes suspended in low ionic strength media was negligible and increased by 10 - to 20 -fold in the presence of salts. This effect was not due to any particular ion but depended on the ionic strength $(\mu)$ of the salts. Maximal binding occurred at $\mu$ between 0.3 and 0.4 and was maintained at even higher ionic concentrations. Cascieri and Liang (1983) also reported that the binding of [ ${ }^{125}$-Bolton Hunter]-SP to rat cortex membranes was minimal in $50 \mathrm{~mm}$ Tris- $\mathrm{HCl}$. Unlike binding to rat brain membranes, $\left[{ }^{3} \mathrm{H}\right] \mathrm{PHY}$ binding to rat submaxillary gland was significant in low and high ionic strength media (Bahouth et al., 1985). The reason for this disparity in the binding characteristics of membranes from two different organs is not clear. Another characteristic effect of the monovalent ions is that chloride-containing salts inhibited the binding when their concentration exceeded $0.3 \mathrm{M}$. This inhibitory effect was unique to chloride ions but is probably not physiologically significant, since it occurs only at about twice its humoral concentration.

The addition of divalent cations had a dual effect on the specific binding of $\left[{ }^{3} \mathrm{H}\right] \mathrm{PHY}$. When $2.5 \mathrm{mM} \mathrm{MnCl}_{2}$ was added, the affinity of 


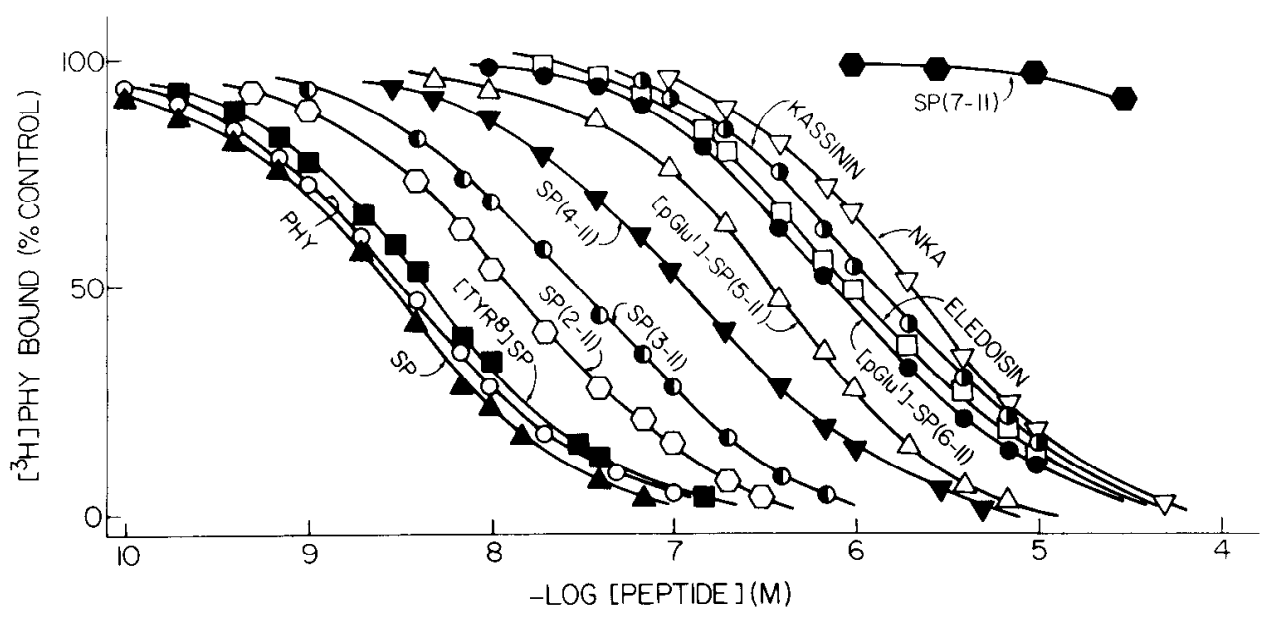

Figure 7. Inhibition of $\left[{ }^{3} \mathrm{H}\right] \mathrm{PHY}$ binding by unlabeled PHY, SP, and structurally related peptides. $\left[{ }^{3} \mathrm{H}\right] \mathrm{PHY}$ was displaced by increasing concentrations of $\mathrm{PHY}, \mathrm{SP}$, and its related peptides. The incubation conditions were as described under "Materials and Methods." Results are expressed as the percentage of the specific binding of $\left[{ }^{3} \mathrm{H}\right]$ $\mathrm{PHY}$, in the absence of unlabeled peptide. All points represent the mean of triplicate determinations of a single experiment. The experiments were repeated two or three times, and the rosults of the analysis of the pooled data, which were calculated with the EBDA program (McPherson, 1983), are summarized in Table IV.

$\left[{ }^{3} \mathrm{H}\right] \mathrm{PHY}$ increased almost 2-fold, from $K_{\mathrm{D}}=6.6 \mathrm{~nm}$ to $3.6 \mathrm{~nm}$. In addition, the $B_{\text {max }}$ of $\left[{ }^{3} \mathrm{H}\right] \mathrm{PHY}$ increased by $35 \%$ (from 55.3 to 74.2 $\mathrm{fmol} / \mathrm{mg}$ of protein). This effect was not due to the increase in the amount of proteins deposited on the filter as judged by the Lowry assay (Lowry et al., 1951). Cascieri and Liang (1983) previously reported that the addition of $5 \mathrm{mM} \mathrm{MnCl}_{2}$ to rat brain cortex membranes increased the binding of [ ${ }^{125}$-Rolton Hunter]-SP by $4-$ to 28 fold. In contrast to the effect of divalent cations on the increase in number of sites and affinity of central nervous system membranes, the divalent cations produced only a modest increase in the binding of $\left[{ }^{3} \mathrm{H}\right] \mathrm{SP}$ and $\left[{ }^{3} \mathrm{H}\right] \mathrm{PHY}$ to rat submaxillary gland membranes, by increasing the $B_{\max }$ by 20 to $40 \%$ without altering the affinity of the SP receptor (Lee et al., 1983; Bahouth et al., 1985; Bahouth and Musacchio, 1985).

The receptor density that we have observed in this sludy is similar to that reported by Perrone et al. (1983) for $\left[{ }^{3} \mathrm{H}\right] \mathrm{SP}$ binding to rat brain membranes $\left(B_{\max }=86.5 \mathrm{fmol} / \mathrm{mg}\right)$. However, our $B_{\max }$ is substantially higher than that reported for $\left[{ }^{3} \mathrm{H}\right] \mathrm{SP}$ binding to rat brain membranes (Hanley et al., 1980) and slices (Quirion et al., 1983a) or [ ${ }^{125}$-Bolton Hunter]-SP binding to rat brain synaptosomes (Viger et al., 1983). This discrepancy is probably due to several factors. One is probably related to the way in which we processed the tissue: we discarded the $900 \times g$ sediment which contains few receptors but a high concentration of proteins, whereas in the work with tissue slices (Quirion et al., 1983a), the $B_{\text {max }}$ has to be calculated for the total proteins. The addition of $2.5 \mathrm{mM} \mathrm{MnCl}_{2}$, which Viger et al. (1983) did not use, is another factor that further contributes to increase the value of the $B_{\max }$ as determined in our laboratory.

The affinity of $\left[{ }^{3} \mathrm{H}\right] \mathrm{PHY}$ determined by saturation Scatchard analysis was $3.6 \mathrm{~nm}$ and that determined by kinetic analysis was $4.4 \mathrm{~nm}$. These values are similar to those previously reported by others: we calculated the $K_{1}$ of $\mathrm{PHY}$ in published studies using the equation of Cheng and Prusoff (1973) and found that the $K_{1}$ of PHY in competing with $\left[{ }^{3} \mathrm{H}\right] \mathrm{SP}$ bound to rat brain membranes and slices was $3.5 \mathrm{nM}$ (Perrone et al., 1983; Quirion et al., 1983a) and $2 \mathrm{nM}$ in competing with [ ${ }^{125}$-Bolton Hunter]-SP bound to rat brain synaptosomes (Viger et al., 1983). The affinity of PHY determined by several pooled competition experiments was $2.7 \mathrm{~nm}$ (Table $\mathrm{V}$ ). It is noteworthy that the affinity of $\left[{ }^{3} \mathrm{H}\right] \mathrm{PHY}$ in rat submaxillary gland is $2.7 \mathrm{~nm}$ (Bahouth et al., 1985), quite similar to the results obtaincd in brain.

The present study was conducted in a high ionic strength medium $(\mu=0.3)$, much higher than all of the previous studies that deal with labeling of the SP receptor in rat brain. We have previously demonstrated that the affinity of $\left[{ }^{3} \mathrm{H}\right] \mathrm{SP}$ decreases from $0.15 \mathrm{~nm}$ in low ionic strength to $2.8 \mathrm{~nm}$ in high ionic strongth modium, whereas $\left[{ }^{3} \mathrm{H}\right]$ PHY has a constant affinity (Bahouth et al., 1985). In consequence, the relative potency of $\mathrm{PHY}$ to inhibit $\left[{ }^{3} \mathrm{H}\right] \mathrm{SP}$ binding increases in high ionic strength.

$\mathrm{PHY}$ and SP were the most potent competitors against $\left[{ }^{3} \mathrm{H}\right] \mathrm{PHY}$ binding with a similar $\mathrm{IC}_{50}$ of 5.6 and $5.9 \mathrm{nM}$, respectively $(p>0.05)$. The relative potency of different SP fragments to compete with $\left[{ }^{3} \mathrm{H}\right]$ PHY was: $\mathrm{SP}>\mathrm{SP}(2-11)>\mathrm{SP}(3-11)>\mathrm{SP}(4-11)>\left[\mathrm{pGlu}{ }^{1}\right]-\mathrm{SP}(5-$ 11) $>$ [pGlu $\left.{ }^{1}\right]-S P(6-11)>>S P(7-11)$. These results are in agreement with those of Quirion et al. (1983b), who reported that PHY is at least as potent as $\mathrm{SP}$ in competing with [ $\left.{ }^{125} 1\right] \mathrm{PHY}$ in rat brain sections in Krebs buffer. Other binding studies are generally in agreement with ours except for the potency of PHY. PHY has been reported to be consistently weaker than SP in competing with [ ${ }^{125} /$-Bolton Hunter] -SP bound to brain mernbranles (Cascieri and Liang, 1983), with [ $\left.{ }^{3} \mathrm{H}\right]$ SP bound to rat brain slices (Quirion et al., 1983a), and with ${ }^{125}$. Bolton Hunter]-SP bound to mouse mesencephalic cells in primary culture (Beaujouan et al., 1982). The affinity profile of the different tachykinins and SP analogues in competing with $\left[{ }^{3} \mathrm{H}\right] \mathrm{PHY}$ indicate that this label interacts with the SP-P receptor and that this binding site is similar to the SP-P receptor in rat submaxillary gland membranes labeled with $\left.\Gamma^{3} \mathrm{H}\right] \mathrm{SP}$ and $\left.\Gamma^{3} \mathrm{H}\right] \mathrm{PHY}$ (Lee et al., 1983; Bahouth et al., 1985).

Manganese doubled the specifically bound $\left[{ }^{3} \mathrm{H}\right] \mathrm{PHY}$. However, in the presence of $1 \mathrm{~mm} \mathrm{Gpp}(\mathrm{NH}) \mathrm{p}$, binding of $\left[{ }^{3} \mathrm{H}\right] \mathrm{PHY}$ was the same regardless of the presence or absence of $\mathrm{Mn}^{2+}$. These observations suggest that guanine nucleotides block the effect of divalent cations. Washing the membranes by centrifugation three times restored the stimulation of binding by $\mathrm{Mn}^{2+}$ in the $\mathrm{Gpp}(\mathrm{NH})$ p-pretreated membranes, indicating that the guanine nucleotide cffects are reversible. This also indicates that the binding sites of the guanine nucleotides and divalent cations are not dissociated from the PHY-binding site during the washing procedure. If the SP receptor is protected from inactivation with a high concentration of PHY, NEM blocks the effect of both divalent cations and guanine nucleotides (Musacchio et al., 1984).

We found that guanine nucleotides inhibited the binding of $\left[{ }^{3} \mathrm{H}\right]$ PHY by only 50 to $60 \%$. This is much less than what was reported by Cascieri and Liang (1983), who showed that Gpp(NH)p and GTP produced a complete inhibition of [ ${ }^{125}$-Bolton Hunter]-SP binding to rat brain membranes suspended in low ionic strength divalent cationcontaining medium ( $50 \mathrm{~mm}$ Tris- $\mathrm{HCl}, 5 \mathrm{~mm} \mathrm{MnCl}_{2}$ ). This discrepancy could be related to the different experimental conditions: we used, in addition to the divalent cations, high ionic strength media, which increase binding in a guanine nucleotide-insensitive manner, while the divalent cation-dependent binding is sensitive to guanine nucleotides.

The effects of divalent cations and guanine nucleotides on $\left[{ }^{3} \mathrm{H}\right]$ $\mathrm{PHY}$ binding suggest that both agents may act on a GTP-binding regulatory protein as is the case of adenylate cyclase-coupled receptors (Rodbell, 1980). However, the experiments of Lee et al. (1983) indicate that the SP receptor is not coupled to adenylate cyclase, at least in the rat salivary glands. Mantyh et al. (1984) recently reported that $\mathrm{SP}$ receptors in the central nervous system 
are intimately related to the inositol phospholipid hydrolysis. These considerations indicate that the central nervous system SP-P receptors coupled to inositol phospholipid hydrolysis may be associated lo a GTP-binding regulatory protein.

Regional distribution of $\left[{ }^{3} \mathrm{H}\right] \mathrm{PHY}$-binding sites in rat brain indicates that these sites are present in all major brain areas. The highest concentration of binding sites was in the olfactory bulb, in agreement with the autoradiographic distribution studies of $\left[{ }^{3} \mathrm{H}\right] \mathrm{SP}$-binding sites in rat central nervous system (Quirion et al., 1983a). In other areas, moderate $\left[{ }^{3} \mathrm{H}\right] \mathrm{PHY}$ binding is observed with a rank order hypothalamus $>$ striatum $>$ hippocampus $>$ midbrain $>$ cortex $>$ medulla $>$ cerebellum. Viger et al. (1983) also reported an uneven distribution of [ ${ }^{125} \mathrm{I}-\mathrm{Bolton}$ Hunter]-SP receptors in rat brain, with a greater receptor density in hypothalamus and the lowest in cerebellum.

This study demonstrates that $\left[{ }^{3} \mathrm{H}\right] \mathrm{PHY}$ labels a physiologically relevant SP receptor in rat brain membranes. The nonspecific binding accounts for only $15 \%$ of the total binding, providing an excellent signal-to-noise ratio for the biochemical characterization of SP receptors in the central nervous system. This study shows that the binding of $\left[{ }^{3} \mathrm{H}\right] \mathrm{PHY}$ to rat brain membranes requires both monovalent and divalent cations.

\section{References}

Bahouth, S. W., and J. M. Musacchio (1985) Specific binding of $\left[{ }^{3} \mathrm{H}\right]$ Substance $P$ to rat submaxillary gland, the effect of ions and guanine nucleotides. J. Pharmacol. Exp. Ther., in press.

Bahouth, S. W., D. M. Lazaro, D. E. Brundish, and J. M. Musacchio (1985) Specific binding of $\left[{ }^{3} \mathrm{H}-\mathrm{Ty}^{8}\right]$ physalaemin to the rat submaxillary gland. Mol. Pharmacol. 27: 38-45.

Beaujouan, J. C., Y. Torrens, A. Herbert, M. C. Daguet, J. Glowinski, and A Prochiantz (1982) Specific binding of an immunoreactive and biologically active ${ }^{125}$-labeled substance $P$ derivative to mouse mesencephalic cells in primary culture. Mol. Pharmacol. 22: 48-55.

Brown, R. D., and J. E. Manno (1978) ESTRIP: a BASIC computer program for obtaining initial polyexponential parameter estimates. J. Pharm. Sci. 67: 1687-1691

Buck, S. H., E. Burcher, C. W. Shults, W. Lovenberg, and T. L. O'Donohue (1984) Novel pharmacology of substance K-binding sites: A third type of tachykinin receptor. Science. 226: 987-989.

Bury, R. W., and M. L. Mashford (1977) A pharmacological investigation of synthetic substance $P$ on the isolated guinea-pig ileum. Clin. Exp. Pharmacol. Physiol. 4: 453-461

Cascieri, M. A., and T. Liang (1983) Characterization of the substance $P$ receptor in rat brain cortex membranes and the inhibition of radioligand binding by guanine nucleotides. J. Biol. Chem. 258: 5158-5164.

Cheng, Y. C., and W. H. Prusoff (1973) Relationship between the inhibition constant $\left(K_{1}\right)$ and the concentration of inhibitor which causes 50 percent inhibition $\left(k_{50}\right)$ of an enzymatic reaction. Biochem. Pharmacol. 22: 30993108

De Robertis, E., A. Pellegrino de Iraldi, G. Rodriguez de Lores Arnaiz, and L. Salganicoff (1962) Cholinergic and non-cholinergic nerve endings in rat brain. I. Isolation and subcellular distribution of acetylcholine and acetylcholinesterase. J. Neurochem. 9: 23-35.

Erspamer, V. A. Anastasi, G Bertaccini, and J. M. Cei (1964) Structure and pharmacological actions of physalaemin, the main active polypeptide of the skin of Physalaemus fuscumaculatus. Experientia 20: 489-490.

Hanlcy, M. R., B. E. B. Sandberg, C. M. Lce, L. L. Iversen, D. E. Brundish and $R$. Wade (1980) Specific binding of ${ }^{3} \mathrm{H}$-Substance $P$ to rat brain membranes. Nature 286: $810-812$
Huidobro-Toro, J. P., C. A. Chelala and J. M. Musacchio (1982) Hydrolysis of substance $P$ and bradykinin by black widow spider venom gland extract. Biochem. Pharmacol. 31: 3323-3328.

Kangawa, K., N. Minamino, A. Fukuda, and H. Matsun (1983) Neuromedin $\mathrm{K}$ : A novel mammalian tachykinin identified in porcine spinal cord. Biochem. Biophys. Res. Commun. 114: 533-540.

Kimura, S., M. Okada, Y. Sugita, I. Kanazawa, and E. Munekata (1983) Novol neuropeptides, Neurokinin-alpha and Neurokinin-beta isolated from porcine spinal cord. J. Jpn. Acad. Ser. B. 59: 101-104.

Kitabgi, P., R. Carraway, J. Van Rietschoten, C. Granier, J. L. Morgat, A. Menez, S. Leeman, and P. Freychet (1977) Neurotensin: Specific binding to synaptic membranes from rat brain. Proc. Natl. Acad. Sci. U. S. A. 74: $1846-1850$

Konishi, S., and M. Otsuka (1974) The effects of substance $P$ and other peptides on spinal neurons of the frog. Brain Res. 65: 397-410.

Lee, C. M., L. L. Iversen, M. R. Hanley, and B. E. B. Sandberg (1982) The possible existence of multiple receptors for substance P. Naunyn Schmiedebergs Arch. Pharmacol. 318: 281-287.

Lee, C. M., J. A. Javitch, and S. H. Snyder (1983) ${ }^{3} \mathrm{H}$-Substance P binding to salivary gland membranes: Regulation by guanyl nucleotides and divalent cations. Mol. Pharmacol. 23: 563-569.

Liang, T., and M. A. Cascieri (1979) Substance P stimulation of amylase release by isolated parotid cells and inhibition of substance $P$ induction of salivation by vasoactive peptides. Mol. Cell. Endocrinol 15: 151-162.

Lin, C. W., and J. M. Musacchio (1983) The determination of dissociation constants for substance $P$ and substance $P$ analogues in the guinea pig ileum by pharmacological procedures. Mol. Pharmacol. 23: 558-562.

Lowry, O. H., N. J. Rosebrough, A. L. Farr, and R. J. Randall (1951) Protein measurement with the Folin phenol reagent. J. Biol. Chem. 193: 265-275.

Mantyh, P. W., R. D. Pinnock, C. P. Downes, M. Goedert, and S. P. Hunt (1984) Correlation between inositol phospholipid hydrolysis and substance $P$ receptors in the CNS. Nature 309: 795-797.

McPherson, G. A. (1983) A practical computer-based approach to the analysis of radioligand binding experiments. Comput. Programs Biomed. 17: $107-114$.

Munson, P. J., and D. Rodbard (1980) LIGAND: A versatile computerized approach for characterization of ligand-binding systems. Anal. Biochem. 107: 220-239

Musacchio, J. M., P. M. Narang, S. W. Bahouth, and D. E. Brundish (1984) Effect of ions and guanine nucleotides on the rat brain substance $P$ receptor. In Substance P. Metabolism and Biological Actions, Taylor and Francis, Inc., Philadelphia, in press.

Perrone, M. H., R. E. Diehl, and D. R. Haubrich (1983) Binding of $\left[{ }^{3} \mathrm{H}\right]$ substance $\mathrm{P}$ receptors in rat brain membranes. Eur. J. Pharmacol. 95: 131-133.

Peterson, G. L. (1977) A simplification of the protein assay method of Lowry et al., which is more generally applicable. Anal. Biochem. 83: 346-356.

Quirion, R., C. W. Shults, T. W. Moody, C. B. Pert, T. N. Chase, and T. L. O'Donohue (1983a) Autoradiographic distribution of substance $P$ receptors in rat central nervous system. Nature 303: 714-716.

Quirion, R., C. W. Shults, S. S. Wolf, R. T. Jensen, C. B. Pert, T. N. Chase, and T. L. O'Donohue (1983b) Autoradiographic localization of substance $P(S P)$ receptors in rat brain: A comparison of binding properties of $\left[{ }^{3} \mathrm{H}\right]$ $\mathrm{SP}$ and $\left[{ }^{125} \mathrm{I}\right]$-SP and $\left[{ }^{125} \mathrm{I}\right]$-physalaemin. In Substance P-Dublin 1983, $\mathrm{P}$ Skrabanek and D. Powell, eds., pp. 55-56, Boole Press, Dublin.

Rodbell, M. (1980) The role of hormone receptors and GTP-regulatory proteins in membrane transducin. Nature 284: 17-22.

Tregear, G. W., H. D. Niall, J. T. Potts, S. E. Leeman, and M. M. Chang (1971) Synthesis of substance P. Nature New Biol. 232: 87-89.

Viger, A., J. C. Beaujouan, Y. Torrens, and J. Glowinski (1983) Specific binding of ${ }^{125}$-substance $P$ derivative to rat brain synaptosomes. J. Neurochem. 40: 1030-1039. 